\title{
THE KANO MODEL USE TO EVALUATE THE PERCEPTION OF INTELLIGENT AND ACTIVE PACKAGING OF SLOVAK CUSTOMERS
}

Ing. Loučanová Erika, PhD.

Technical University in Zvolen, The Faculty of Wood Sciences and Technologies,

Department of marketing, trade and world forestry, Slovak republic loucanova@tuzvo.sk

\section{Ing. Nosálová Martina, PhD.}

Technical University in Zvolen, The Faculty of Wood Sciences and Technologies,

Department of marketing, trade and world forestry, Slovak republic nosalova@tuzvo.sk

doc. Ing. Parobek Ján, PhD.

Technical University in Zvolen, The Faculty of Wood Sciences and Technologies, Department of marketing, trade and world forestry, Slovak republic parobek@tuzvo.sk prof. Ana Dopico

University of Vigo, 36005 Pontevedra, Spain adopico@uvigo.es

(Received: November 2017; Accepted February 2018)

\begin{abstract}
Intelligent innovation represents any autonomic change with positive impact to the customer. They increase the comfort of the customer and concurrently they represent more effective, more economical, healthier and safer solution. This term is not so usual in Slovakia, however intelligent innovation are present on the market. For that in the article intelligent innovation assessment, we focused on intelligent and active packaging, the occurrence of which we have mostly noticed on the Slovak market. The paper deals with the evaluation of the perception of packaging innovations by using the Kano model. According to research results, intelligent and active packaging influence customers and therefore constitutes a tool of competitiveness in Slovakia. However, considering the specification of their requirements, the degree of impact is very variable and specific to customers of different gender and age.
\end{abstract}

Key words: packaging, innovation, intelligent and active packaging.

J.E.L. CODES: O31, 032

\section{Introduction}

Nowadays the success company is company that is able promptly and in time reacts to changing market conditions; fulfill the customers' needs and so to be 
competitiveness. The key is innovation - new products and services that are original, different from other and fulfill the market requirements.

The global trends highlight the continual accelerating pace of innovation entrances, growth of global competitiveness and technologically oriented innovation. One type of that kind of innovation are intelligent and active packaging that represents multidimensional process of product competitiveness increasing by using creative, strategic, intuitive and technology orientated packaging. They represent innovation with the ability to bring competitiveness advantages.

For intelligent innovation assessment, we focused on intelligent and active packaging, the occurrence of which we have mostly noticed on the Slovak market. The aim of the paper is to monitor the awareness of intelligent and active packaging in Slovakia by using the Kano model.

\section{Literature Review}

The classic approach to the innovation classification is the approach of Joseph Schumpeter (1931, In Zaušková \& Loučanová, 2008), who initially considered innovation as any positive change in the production organism.

One of the earliest authors of the concept of intelligent innovation is John A. Cogliandro (2007), who in his thesis does not consider intelligent innovation as a method or quickly acquired rich program for the customer, but a multidimensional process supported by a culture of strategically balanced and creative problem solving, intuitive sense for the market and the pursuit of success. Intelligent innovation and success are the result of better performance of many tasks, including management, motivation, finance, decision making and coordinating authority responsibilities. Intelligent innovation attempts to prove, promote, explain and provide information about the status of the subject and, if necessary, manage it.

Luo Zongwei (2014) defined intelligent innovation in the field of medicine as smart and intelligent computational methods, which are nowadays exclusive and necessary for the production and optimization of goods (objects, products, processes). New and innovative computing tools and algorithms are consistently developed and applied to develop new product elements and their components in the form of smart or intelligent devices that enable to analyze larger data files simultaneously on multi-processor cloud systems.

The term of intelligent innovation is not so usual in Slovakia, however intelligent innovation are present on the market. Loučanová (2016) based on the essential definitions of innovation defines intelligent innovation as "any autonomic change with positive impact to the customer". They increase the comfort of the customer 
and concurrently they represent more effective, more economical, healthier and safer solution.

In Slovakia, intelligent innovations are the most common as smart intelligent products, whether it's intelligent appliances such as a refrigerator, microwave and other, different thermostats, light controls, and wider smart concepts, such as smart homes and intelligent cities. However, particularly we have noticed intelligent and active packaging on the Slovak market (Loučanová et al., 2017).

As a result of global change and progress in recent decades, approach to packaging materials and packaging techniques also changes. Innovative packaging is the result of creative, unconventional thinking beyond the usual thinking framework.

Active and intelligent packaging is (Ahvenainen, 2000):

$>$ Active packaging changes the condition of packaged food and prolongs the shelf life or increases security while maintaining the quality of the packaged food at the same level. Active packaging represent shift in the protection function from passive to active. The packaging is not only a passive barrier between the product and its environment, but the aim of protective function is to actively protect the product (Yam et al., 2005) and actively changes the condition of the package to extend shelf life or improve food safety (Kačeňák, 2011). According to the way in which they affect the characteristics of the product the active packaging can be classified as follows (Sosnovcová, 2008):

- absorbers - active packaging systems based on absorption,

- emitters - active packaging systems based on the release of substances.

$>$ Intelligent packaging monitors the status of packaged food and provides information on quality during transportation and storage. Intelligent packaging is associated with the performance of smart features and intelligent functions (such as detecting, sensing, recording, tracing, communicating, and applying scientific logic) to: facilitate decision making to extend shelf life, enhance safety, improve quality, provide information, and warn about possible problems (Yam et al., 2005).

Consumers' attitude towards the product packaging has changed, whereas, according to earlier studies the packaging has been described as an indispensable part of the product, more recent studies indicates its change to an attractive part of the product. However, the first impression of the packaging to the purchase does not persist if the packaging is not "user-friendly" and functional. The packaging must be simple to use, providing relevant information and fitting into storage (Löfgren \& Witell, 2005).

Many consumer behavior studies investigate the perception of packaging by consumers - product rating influences the purchasing intentions and attitudes of consumers (Kauppinen-Räisänen \& Luomala, 2010, Wilke et al., 2011, In Prakash 
\& Pathak, 2017). Consumer attitudes towards active and intelligent packaging vary from country to country. According to Brennan and Crandison (2011), active packaging materials are generally accepted in the US, Australia, Japan, but much less in European countries. On the other hand, some intelligent packaging materials are more widespread in European countries. The reasons for these different attitudes are not clear, but may be partly due to cultural differences and lack of understanding of the features and benefits.

Innovation management and innovation penetration cannot exist without examining consumer preferences and attitudes, because new product acceptance is ultimately an important factor in success. This approach can help clarify, predict or influence adaptation or refusal of innovation as regards (Trommsdorf \& Steinhoff, 2009):

- The willingness to accept product innovation or innovative product characteristics a series of innovations failed because they were not clearly explained to customers.

- Exploring the psychological perception of innovation - the issue of recognizing customers' future benefits of product innovation.

- Analysis of attitudes to innovations.

\section{Methodology}

A perception of consumers' attitudes towards intelligent and active packaging in Slovakia is a key issue that can significantly affect the access of companies to the innovation process. To determine the awareness and attitudes of consumers the Kano model was used. The aim of the Kano model is to capture customers' opinion according to the requirements of an observed object (Goodpasture, 2003). That model was used, because it is useful in gaining a thorough understanding of a customer's needs thus expanding market research opportunities through their integration among participants in the innovation process (Loučanová, 2016; Tomek \& Vávrová, 2009; Trommsdorff \& Steinhoff, 2009). Like many big data collection methods, however, analyzing this type of data is certainly not easy. The potential disadvantage is also the length of the survey because of doubling the number of questions when asking possitive and negative question, what can be frustrating for the respondents. In the conditions of Slovakia, such research has not yet been carried out.

The first step of the Kano model methodology is to identify the main requirements of consumers according to the intelligent and active packaging. The pilot survey was conducted and it consisted of descriptive questions - to monitor the experience of using the product, decisive criteria for purchasing, as well as new features that would be welcomed by the product. 
Based on customers' responses to those questions, the requirements (future variables in Kano models) for the product were generated as follows: the perception of intelligent and active packaging, their availability, and perception of their functionality, voice performance, freshness indicators, and attractiveness of these packages for customers, perception of advertisement for intelligent and active packaging and perception of price. According to that pre-queried customer requirements a positive and negative question is formulated to each single requirement and a questionnaire is formulated. The respondents during the survey can response within the range of the Likert scale (strong approval, partial approval, neutral attitude, partial disapproval, strong disapproval).

The validity of the survey was determined by the methodology for respondents' sample calculation:

$$
\mathrm{n}=\frac{\mathrm{Z}_{1 \alpha / 2^{2} * \mathrm{~S}^{2}}}{\mathrm{H}^{2}}
$$

where:

z1-a / 2 - required confidence level

$\mathrm{H}$ - margin of error

$\mathrm{s}$ - standard deviation

The sample of respondents was determined at a confidence level of $99 \%$, with a tolerance error of $+/-5 \%$ of the standard deviation of 0.5 , which at the given data represents the value of 665.64 , i.e., 666 respondents. The survey was conducted between September and December 2016. There were 767 respondents and the results according to a confidence level, standard deviation, and margin of error are relevant.

Table 1 Kano Model to evaluate customer requirements

\begin{tabular}{|c|c|c|c|c|c|c|}
\hline & \multicolumn{5}{|c|}{ Negatively formulated question } \\
\hline & & $\begin{array}{l}\text { Strong } \\
\text { agree }\end{array}$ & $\begin{array}{c}\text { Partially } \\
\text { agree }\end{array}$ & $\begin{array}{l}\text { Neutral } \\
\text { attitude }\end{array}$ & $\begin{array}{l}\text { Partially } \\
\text { disagree }\end{array}$ & $\begin{array}{c}\begin{array}{c}\text { Strong } \\
\text { disagree }\end{array} \\
\end{array}$ \\
\hline \multirow{5}{*}{ 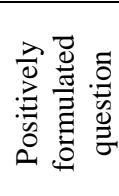 } & Strong agree & $\mathrm{Q}$ & $\mathrm{A}$ & $\mathrm{A}$ & $\mathrm{A}$ & $\mathrm{O}$ \\
\hline & Partially agree & $\mathrm{R}$ & I & I & I & $\mathrm{M}$ \\
\hline & Neutral attitude & $\mathrm{R}$ & $\mathrm{I}$ & I & I & $\mathrm{M}$ \\
\hline & Partially disagree & $\mathrm{R}$ & I & I & I & $\mathrm{M}$ \\
\hline & Strong disagree & $\mathrm{R}$ & $\mathrm{R}$ & $\mathrm{R}$ & $\mathrm{R}$ & Q \\
\hline
\end{tabular}

Source: Ducák et al., 2006.

For each variable, individual responses to the positively and negatively asked question (statement) by the Kano cross rule (Table 1) are individually evaluated to specify the requirements for the Intelligent and active packaging as a survey object. 
This approach classifies individual measured variables into requirements: mandatory $(\mathrm{M})$, one-dimensional $(\mathrm{O})$, attractive $(\mathrm{A})$, irrelevant $(\mathrm{I})$ or questionable (Q).

Individual categories of product requirements that affect customer satisfaction can be characterized by Chen et al. (2010) as follows:

Mandatory requirements (M) are obligatory requirements that customers consider as normal and are automatically expected. These requirements can be identified as primary or basic. Customers deal with them only in the event of non-compliance. Identifying them is an elementary importance mainly because even though their fulfillment is reflected in customers' satisfaction, their deficit and failure is reflected in customers' dissatisfaction immediately as they realize it.

One-dimensional requirements $(\mathrm{O})$ are represented by those product attributes that lead to fulfillment and satisfaction or in the event of non-compliance to customers dissatisfaction, i.e., the higher the degree of compliance with these requirements, the customers are more satisfied, but compared to the mandatory requirements customers automatically do not expect them.

Attractive requirements (A) have a clear impact on customers' satisfaction because they are requirements that customers did not expect. If attractive requirements are not met, it does not reflect customer dissatisfaction.

Reverse requirements (R), in some literature (Ducar et al., 2006, Ullah \& Tamaki, 2011) also called contradictory or exactly opposite, represent product attributes where customers react oppositely.

Irrelevant requirements (I) do not have any influence on customers. This category involves the attributes that are not critical for customers and their presence or absence does not affect their satisfaction or dissatisfaction (Ducár et al. 2006).

In addition to the above mentioned categories of product requirements, the Kano model also identifies the inconclusive, respectively questionable requirements (Q). These represent a controversial outcome, which relates either to incorrectly formulated questions or it is caused by lack of understanding by customers.

Categorized customer requirements for the surveyed subject are then expressed in percents where the highest percentage category identifies the specific category of the studied packaging attribute. Percentage expression of the identified specific category represents its share of the identified requirements of the monitored attribute.

\section{Result and discussion}

New innovations provide companies new competitive advantages that company can use for their benefit also depending on understanding and acceptance by customers. 
Such innovation in the Slovak market is intelligent and active packaging and Kano model was used to determine the consumers' attitudes towards that innovative form of packaging in Slovakia. We examined the perception of intelligent and active packaging, their availability, perception of their functionality, voice performance, freshness indicators, attractiveness of these packages for customers, perception of advertisement for intelligent and active packaging and perception of price.

Based on the processed database from the intelligent innovation mapping survey (focusing on intelligent and active packaging) and their solutions as a tool of competitiveness in Slovakia, the results were evaluated (Table 2) and it is clear that they have no or even minimal impact on the customers.

Table 2 Kano Model to evaluate customer requirements

\begin{tabular}{|c|c|c|c|c|c|c|}
\hline & \multicolumn{2}{|c|}{ Requirements } & \multirow[b]{2}{*}{$\mathrm{O}$} & \multirow[b]{2}{*}{$\mathrm{R}$} & \multirow[b]{2}{*}{ I } & \multirow[b]{2}{*}{ Q } \\
\hline & M & A & & & & \\
\hline $\begin{array}{l}\text { Concept of } \\
\text { intelligent and } \\
\text { active packaging }\end{array}$ & 3,13 & 31,03 & 3,78 & 19,56 & 32,72 & 9,78 \\
\hline Availability & 1,43 & 6,39 & 0,39 & 36,64 & 52,41 & 2,74 \\
\hline Awareness & 1,56 & 6,65 & 0,39 & 44,46 & 38,98 & 7,95 \\
\hline Functionality & 4,43 & 8,34 & 1,17 & 22,16 & 59,84 & 4,04 \\
\hline $\begin{array}{l}\text { Voice } \\
\text { performance }\end{array}$ & 10,82 & 5,74 & 3,13 & 20,47 & 55,41 & 4,43 \\
\hline $\begin{array}{l}\text { Attractiveness of } \\
\text { packaging }\end{array}$ & 5,87 & 14,34 & 2,74 & 20,34 & 50,20 & 6,52 \\
\hline Advertisement & 1,17 & 9,91 & 0,78 & 33,77 & 49,54 & 4,82 \\
\hline $\begin{array}{l}\text { Freshness } \\
\text { indicators }\end{array}$ & 0,91 & 15,65 & 0,39 & 22,16 & 25,29 & 35,59 \\
\hline Price & 2,35 & 4,30 & 1,04 & 41,07 & 45,11 & 6,13 \\
\hline
\end{tabular}

Intelligent innovations, focusing on intelligent and active packaging, are insignificant requirements for customers, represented by attributes that are not decisive for customers and their fulfillment or failure does not affect their satisfaction or dissatisfaction (I). At the same time, they are insignificant from the point of view of the competitiveness of the product. This may be due to the fact that this issue is not known to the respondent, they are not familiar with it and therefore they are unable to take an opinion on its individual specifications.

What is remarkable, however, is that the concept of intelligent and active packaging is very attractive (A) to customers (as evidenced by a $31.03 \%$ response rate). This means that intelligent and active packaging issue represents attractive requirements with clear effect on customers' satisfaction. If attractive requirements 
are not fulfilled it does not reflect the customer's dissatisfaction, but their fulfillment and presence of this attribute in the product can have a very positive influence on the customers' satisfaction.

Our statement about customers' low awareness and knowledge of intelligent and active packaging is also confirmed by the fact there is a large number of reverse requirements (R) - parameter accessibility with $36.64 \%$ relative share and parameter awareness of this issue with $44.46 \%$ relative share. This means that customer awareness and availability of intelligent and active packaging in Slovakia is low. Customers do not recognize intelligent and active packaging, do not know whether intelligent and active packaging is available on the market and therefore cannot positively evaluate its availability on the Slovak market.

However, we can also infer the potential study limitation - a lack of awareness among respondents about that issue, which could have been reflected in responses that the respondents did not clearly answer because this issue is unfamiliar to them. However, the Kano model was used as the primary method of this research, because it identifies these limits as Q questionable requirements.

By increasing awareness of intelligent and active packaging, customers' ability to evaluate the availability of these innovations could then be improved. Consequently, on the basis of the findings, it is possible to recommend what measures it is necessary to choose for the appropriate distribution policy of the given innovations so that customers meet their requirements and their satisfaction is fulfilled. It is appropriate, such reverse requirements (R), which do not influence the customer, to innovate in a way that will represent the competitive advantage of the product in the future.

Identified attributes are used to help the customer discover needs that they've never thought about before, to discover this "unknown need" and enlighten the consumer, to sort of engage that "awe effect." Having concurrent excitement attributes within a product can provide a significant competitive advantage over a rival (12manage, 2018). On the basis of this, since the concept of intelligent and active packaging is attractive to customers but their awareness is low, it is necessary to focus on raising awareness, thereby when identifying by customers the intelligent and active packaging can provide a competitive advantage of products.

After a deeper analysis of several factors, we can conclude that intelligent innovations and their solutions as a tool for competitiveness in Slovakia have different impacts on customers in different age categories. The positive impact in terms of increasing the competitiveness of products in Slovakia through intelligent and active packaging can only be seen in age groups 15-40. For this target group the implementation of intelligent features in innovation creation represents an 
increase in the competitiveness of these products within this target group. On the contrary, for age category 41 years and over such innovations are experiencing negatively, and with increasing age dissatisfaction is increasing too.

These findings are consistent with Kalamárová et al (2017) according to which survey results, the awareness of those innovative forms of packaging in Slovakia is very low. The majority of respondents do not know what intelligent and active packaging is and they did not meet such a term. The lowest awareness of that kind of packaging is among older respondents in the age of 41 years and more.

Accordingly it is important to raise awareness of intelligent and active packaging in Slovakia by focusing on the target group of 15-40 years, and then it is high prerequisite for increasing the competitiveness of products with just these packaging.

\section{Conclusions}

The research results have clearly confirmed that customer awareness of intelligent innovations in Slovakia is still at a very low level. Customers do not recognize their individual parameters or identify them and therefore do not positively evaluate their features.

By increasing awareness of intelligent innovations, customers 'ability to evaluate their positives can be further improved and, in the future, they have the potential to represent a competitive advantage for products to meet customers' needs and to increase their satisfaction.

Based on these analyzes, the publication provides both theoretical and practical information for innovators in the field of intelligent innovation, namely intelligent and active packaging. The benefit is the possible application of acquired theoretical knowledge in their implementation in practice, leading to an increase in the performance of companies in their investment decisions in the context of innovation processes. According to intelligent innovation the company must understand the customer's needs and attitudes and then subsequently find the right means of communication with customers. Definitely innovation diffusing and management cannot exist without customer research since innovation acceptation is ultimately an important factor of innovation success.

\section{Acknowledgement}

The authors would like to thank the European Cooperation in the field of Scientific and Technical Research - COST and to the Scientific Grant Agency of the Ministry of Education, Science, Research and Sport of the Slovak Republic and the Slovak Academy of Sciences. This paper is an output of COST Action FP1405 "Active and Intelligent Fibre-Based Packaging - Innovation and Market 
Introduction (ACTINPAK)", the Grant project 1/0756/16 "Identification of consumers' segments according to their affinity for environmental marketing strategies of business entities in Slovakia".

\section{References}

1. Ahvenainen, R. (2000). Novel food packaging techniques. Woodhead Publishing Limited.

2. Brennan, J.C., \& Crandison, A.S. (2011). Food processing handbook. Wiley.

3. Chen, L.S. et al. (2010). Kano Model : a Novel Approach for Discovering ttractive Quality Elements. Total Quality Management, 21 (11), pp. 1189-1214.

4. Cogliandro, J. A., (2007). Intelligent Innovation: Four Steps to Achieving a Competitive Edge. Ross Publishing.

5. Ducár, S., Naščáková, J., \& Malák, M. (2006). Návrh systému merania spokojnosti zákazníkov Kano modelom. Transfer inovácií, 9, 137-139.

6. Goodpasture, J. (2003). Quantitative Methods in Project management. USA: J. Ross Publishing.

7. Kačeňák, I. (2011). Trendy rozvoja potravinárskej obalovej techniky. Bratislava: Vydavatel'stvo Ekonóm.

8. Kalamárová, M., Loučanová, E., \& Parobek, J. (2017). Consumer perception of active and intelligent packaging in Slovakia. Global Scientific Conference: Management and Economics in Manufacturing, 1, pp. 25-30.

9. Kauppinen-Räisänen, H., \& Luomala, H. T. (2010). Exploring consumers' productspecific colour meanings. Qualitative Market Research: An International Journal, 13, pp. 287-308.

10. Löfgren, M., \& Witell, L. (2005). Kano's Theory of Attractive Quality and Packaging. The Quality Management Journal, 12 (3).

11. Loučanová, E. (2016). Inovačné analýzy a stratégie. Zvolen: Technická Univerzita vo Zvolene.

12. Loučanová, E. (2016). Stratégie environmentálne orientovanej produktovej politiky inovácií vo vzt’ahu eko-inovácií a biomimikry. Posterus, 9(2).

13. Loucanova, E., Kalamarova, M. \& Parobek, J. (2017). The Innovative Approaches to Packaging - Comparison Analysis of Intelligent and Active Packaging Perceptions in Slovakia. Studia Universitatis ,Vasile Goldis” Arad - Economics Series, 27(2), pp. 33-44.

14. Loučanová, E., Kalamárová, M., \& Parobek, J. (2017). Inteligentné inovácie a ich riešenia ako nástroj konkurencieschopnosti. Zvolen : Technická univerzita vo Zvolene.

15. Loucanova, E., Parobek, J. \& Kalamarova, M. (2016). The Perception of Respondents of Packaging Innovations in Slovakia. Studia Universitatis „Vasile Goldis" Arad-Economics Series, 26(3), pp. 33-43. 
Loučanová E., Nosálová M., Parobek J., Dopico A. (2018)

The Kano Model use to evaluate the perception of intelligent and active packaging of Slovak customers

16. Luo Zongwei, (2014). Smart Manufacturing Innovation and Transformation: Interconnection and Intelligence. Business Science Reference, IGI Global, UAS.

17. Prakash, G., \& Pathak, P. (2017). Intention to buy eco-friendly packaged products among young consumers of India: A study on developing nation. Journal of Cleaner Production, 141, pp. 385-393.

18. Sosnovcová, J. (2008). Aktivní a inteligentní obalové systémy pro balení potravin. Brno: Vedecký výbor pro potraviny.

19. Tomek, G., Vávrová, V. (2009). Jak zvýšit konkurenční schopnost firmy. Praha : C. H. Beck.

20. Trommsdorf, V., \& Steinhoff, F. (2009). Marketing inovací. C. H. Beck, Praha.

21. Ullah, S. A. M. M., \& Tamaki J. (2011). Analysis of Kano-model-based customer needs for product development. Systems Engineering, 14 (2), pp. 154-172.

22. Yam, K.L., Takhistov, P.T., \& Miltz, J. (2005). Intelligent Packaging: Concepts and Applications. Journal of Food Science, 70(1).

23. Zaušková, A., \& Loučanová, E. (2008). Inovačný manažment. Vydavatel'stvo TU, Zvolen. 